\title{
The Creative Experiences Questionnaire (CEQ): A brief self-report measure of fantasy proneness
}

Citation for published version (APA):

Merckelbach, H. L. G. J., Horselenberg, R., \& Muris, P. E. H. M. (2001). The Creative Experiences

Questionnaire (CEQ): A brief self-report measure of fantasy proneness. Personality and Individual Differences, 31(6), 987-995. https://doi.org/10.1016/S0191-8869(00)00201-4

Document status and date:

Published: 01/01/2001

DOI:

10.1016/S0191-8869(00)00201-4

Document Version:

Publisher's PDF, also known as Version of record

\section{Please check the document version of this publication:}

- A submitted manuscript is the version of the article upon submission and before peer-review. There can be important differences between the submitted version and the official published version of record.

People interested in the research are advised to contact the author for the final version of the publication, or visit the DOI to the publisher's website.

- The final author version and the galley proof are versions of the publication after peer review.

- The final published version features the final layout of the paper including the volume, issue and page numbers.

Link to publication

\footnotetext{
General rights rights.

- You may freely distribute the URL identifying the publication in the public portal. please follow below link for the End User Agreement:

www.umlib.nl/taverne-license

Take down policy

If you believe that this document breaches copyright please contact us at:

repository@maastrichtuniversity.nl

providing details and we will investigate your claim.
}

Copyright and moral rights for the publications made accessible in the public portal are retained by the authors and/or other copyright owners and it is a condition of accessing publications that users recognise and abide by the legal requirements associated with these

- Users may download and print one copy of any publication from the public portal for the purpose of private study or research.

- You may not further distribute the material or use it for any profit-making activity or commercial gain

If the publication is distributed under the terms of Article $25 \mathrm{fa}$ of the Dutch Copyright Act, indicated by the "Taverne" license above, 


\title{
The Creative Experiences Questionnaire (CEQ): a brief self-report measure of fantasy proneness
}

\author{
Harald Merckelbach ${ }^{\mathrm{a}, *}$, Robert Horselenberg ${ }^{\mathrm{a}}$, Peter Muris ${ }^{\mathrm{b}}$ \\ ${ }^{a}$ Department of Experimental Psychology, Maastricht University, PO Box 616, 6200, MD Maastricht, \\ The Netherlands \\ ${ }^{\mathrm{b}}$ Department of Medical and Clinical Psychology, Maastricht University, 6200 MD, Maastricht, The Netherlands
}

Received 28 April 2000; received in revised form 4 October 2000; accepted 16 October 2000

\begin{abstract}
The current article describes the psychometric qualities of the Creative Experiences Questionnaire (CEQ), a brief 25-item self-report measure of fantasy proneness. Findings indicate that the CEQ demonstrates adequate test-retest stability and internal consistency. CEQ scores appear not to be related to social desirability. The CEQ was found to be strongly correlated with a concurrent measure of fantasy proneness. Furthermore, there are substantial correlations between the CEQ and standard measures of absorption, schizotypy, and dissociation. Bearing in mind that these constructs are thought to be intimately linked to fantasy proneness, this pattern of correlations supports the validity of the CEQ. The CEQ might be fruitfully used as a brief research scale in several domains (e.g. studies on pseudomemories). (C) 2001 Elsevier Science Ltd. All rights reserved.
\end{abstract}

Keywords: Fantasy proneness; Absorption; Schizotypy; Dissociation

\section{Introduction}

The concept of fantasy proneness was introduced by Wilson and Barber (1983) to refer to a set of distinct and related characteristics of a small group of people whom they labelled fantasizers. Wilson and Barber described the discovery of fantasy proneness as a serendipitous result of their

* Corresponding author. Tel.: + 31-43-3881945; fax: +31-43-3881908.

E-mail address: h.merckelbach@psychology.unimaas.nl (H. Merckelbach). 
studies on hypnotic susceptibility. These authors focused on a sample of excellent hypnotic individuals and observed that they often displayed an extensive and deep involvement in fantasy. Wilson and Barber conducted in-depth interviews with these individuals and identified an array of features that they believed to be typical for fantasy proneness. These include spending a large part of the time fantasizing, having fantasies with hallucinatory (i.e. "real as real") intensities, reporting vivid childhood memories, experiencing strong bodily concomitants of fantasies, having out-of-body and other paranormal (e.g. telepathic) experiences, and having intense religious experiences.

Subsequent research has shown that the association between hypnotizability and fantasy proneness is less substantial than assumed by Wilson and Barber (1983). A good example is provided by the study of Braffman and Kirsch (1999) who noted that the link between fantasy proneness and hypnotic suggestibility disappears when one controls for participants' expectancies. More recent research has also questioned Wilson and Barber's claim that fantasy proneness constitutes a unitary personality type (e.g. Lynn \& Rhue, 1988, p. 43). Meanwhile, there are some commonalities in the backgrounds of fantasy prone individuals. More specifically, Rhue and Lynn (1987) found evidence that supports Wilson and Barber's speculations about the different developmental pathways that may contribute to fantasy proneness in later life. For example, some fantasy prone adults in the Rhue and Lynn study reported strong parental encouragement to engage in imaginary activities. Other fantasy prones, however, reported a heightened frequency of aversive childhood events. In these cases, a profound fantasy life may have become a means to cope with or escape from negative experiences (see also Lawrence, Edwards, Barraclough, Church \& Hetherington, 1995).

The concept of fantasy proneness has been linked to a broad range of phenomena. Thus, some studies noted that there is a correlation between scores on inventories tapping fantasy proneness and the intensity of paranormal experiences (e.g. UFO experiences; Spanos, Cross, Dickson \& DuBreuill, 1993). Furthermore, there are good reasons to believe that individuals who score high on fantasy proneness are more susceptible to develop and accept detailed pseudomemories (e.g. Hyman \& Billings, 1998). Finally, a number of studies have found a substantial overlap between the traits of absorption, dissociativity, and schizotypy, on the one hand, and fantasy proneness, on the other hand (see for reviews, Kihlstrom, Glisky \& Angiulo, 1994; Lynn \& Rhue, 1988).

So far, most research on fantasy proneness relied on several versions of the Inventory of Childhood Memories and Imaginings (ICMI), which is a dichotomous (yes/no) self-report scale originally developed by Wilson and Barber (1981). The original scale contained 103 items, but shorter versions of the ICMI have also been in use (e.g. Lynn \& Rhue, 1988). In the context of our studies on the link between dissociation and fantasy proneness in normal subjects (e.g. Merckelbach, Muris \& Rassin, 1999), we have found it difficult to locate the various versions of the ICMI in the literature and to obtain psychometric information about them. To the present authors' knowledge, the report by Myers (1983) on the 48-item version of the ICMI is the only publication describing psychometric data about the ICMI. Note, however, that Myers' ICMI version is intended to measure fantasy proneness in children and adolescents. As well, like other ICMI versions, Myers' instrument remains a lengthy scale. With these considerations in mind, we decided to develop a brief research instrument for measuring fantasy proneness, which we termed the Creative Experiences Questionnaire (CEQ). While we are well aware of the fact this is not a 
very precise name for our scale, we chose to avoid references to "fantasy" because this term might have negative connotations for some respondents.

\section{Method}

\subsection{Item construction}

Our starting point was the original Wilson and Barber (1983) paper. From their listing of 40 fantasy proneness characteristics, we derived a first set of items. We then had colleagues check these items to remove: (1) items that might be too invasive; (2) ambiguous items; and (3) items that overlap too much with measures of highly related constructs and, therefore, might contribute to tautological findings (e.g. Nicholls, Licht \& Pearl, 1982). Examples of potentially invasive items are: having vivid sexual fantasies, and having had false pregnancies. Examples of ambiguous items are: sensitivity to social norms, ability to heal other people, and experiences of "automatic writing". Examples of items that overlap with other measures (e.g. cognitive failures, schizotypy, childhood abuse,) are: difficulties when driving, believing that one has mental influence over electric appliances, and having had a stressful early life due to a mother who deserted the family, and/or physical abuse, and/or unstable living conditions. As we were especially interested in the fantasy proneness-dissociation link, we sought to reduce item and format overlap with dissociation measures, notably the Dissociation Experiences Scale (DES; Bernstein \& Putnam, 1986), as much as possible. Thus, items addressing amnesia for traumatic events were deleted from the final version. Two CEQ items (i.e. "I often confuse fantasies with real memories" and "I sometimes feel that I have an out of body experience") clearly overlap with some DES items (e.g. "not sure whether one has done something or only thought about it" and "feeling as though one's body is not one's own", respectively), but were retained in the final CEQ version because they are presented by Wilson and Barber as hallmark features of fantasy proneness. Thus, Wilson and Barber (p. 353) noted that " $85 \%$ of the fantasizers (as contrasted to $24 \%$ of the subjects in the comparison group) stated that they tend to confuse their memories of their fantasies with their memories of actual events." Similarly, these authors concluded that "the overwhelming majority of the subjects $(88 \%)$ in the fantasy proneness group, as contrasted to few $(8 \%)$ in the comparison group, report having out of body experiences" (Wilson \& Barber, p. 360).

Our final CEQ version consisted of $25 \mathrm{yes} /$ no items (Table 1). Some items allude to the developmental antecedents of fantasy proneness. Other items have to do with intense elaboration of and profound involvement in fantasy and daydreaming. Still others pertain to the concomitants and consequences of fantasizing. Yes-answers to CEQ items are summed to obtain a total score (range: 0-25), with higher scores indicating higher levels of fantasy proneness.

\section{Results}

Over the past 4 years, we have conducted a number of studies that addressed reliability and validity of the CEQ as a measure of fantasy proneness. Below, we summarize the main results (see for more detailed information, Merckelbach, Muris, Schmidt, Rassin \& Horselenberg, 1998). 
Table 1

Items of the CEQ and percentage endorsement and corrected item-total correlations in a sample students and university employees $(n=332)$

\begin{tabular}{|c|c|c|}
\hline Items & Yes $(\%)$ & Corrected item-total $r$ \\
\hline $\begin{array}{l}\text { 1] As a child, I thought that the dolls, teddy bears, } \\
\text { and stuffed animals that I played with were living creatures. }\end{array}$ & 34 & 0.38 \\
\hline $\begin{array}{l}\text { 2] As a child, I strongly believed in the existence of dwarfs, } \\
\text { elves, and other fairy tale figures. }\end{array}$ & 45 & 0.35 \\
\hline 3] As a child, I had my own make believe friend or animal. & 29 & 0.26 \\
\hline $\begin{array}{l}\text { 4] As a child, I could very easily identify with the main character } \\
\text { of a story and/or movie. }\end{array}$ & 83 & 0.17 \\
\hline $\begin{array}{l}\text { 5] As a child, I sometimes had the feeling that I was someone else } \\
\text { (e.g., a princess, an orphan, etc.). }\end{array}$ & 42 & 0.39 \\
\hline $\begin{array}{l}\text { 6] As a child, I was encouraged by adults (parents, grandparents, } \\
\text { brothers, sisters) to fully indulge myself in my fantasies and daydreams. }\end{array}$ & 28 & 0.23 \\
\hline 7] As a child, I often felt lonely. & 20 & 0.27 \\
\hline $\begin{array}{l}\text { 8] As a child, I devoted my time to playing a musical instrument, } \\
\text { dancing, acting, and/or drawing. }\end{array}$ & 69 & 0.21 \\
\hline 9] I spend more than half the day (daytime) fantasizing or daydreaming. & 23 & 0.36 \\
\hline $\begin{array}{l}\text { 10] Many of my friends and/or relatives do not know that I have } \\
\text { such detailed fantasies. }\end{array}$ & 36 & 0.31 \\
\hline 11] Many of my fantasies have a realistic intensity. & 53 & 0.31 \\
\hline 12] Many of my fantasies are often just as lively as a good movie. & 48 & 0.37 \\
\hline 13] I often confuse fantasies with real memories. & 14 & 0.16 \\
\hline 14] I am never bored because I start fantasizing when things get boring. & 43 & 0.43 \\
\hline $\begin{array}{l}\text { 15] Sometimes I act as if I am somebody else and I completely } \\
\text { identify myself with that role. }\end{array}$ & 24 & 0.41 \\
\hline 16] When I recall my childhood, I have very vivid and lively memories. & 58 & 0.22 \\
\hline 17] I can recall many occurrences before the age of three. & 12 & 0.24 \\
\hline $\begin{array}{l}\text { 18] When I perceive violence on television, I get so into it that } \\
\text { I get really upset. }\end{array}$ & 26 & 0.20 \\
\hline 19] When I think of something cold, I actually get cold. & 35 & 0.19 \\
\hline 20] When I imagine I have eaten rotten food, I really get nauseous. & 38 & 0.18 \\
\hline $\begin{array}{l}\text { 21] I often have the feeling that I can predict things that are bound } \\
\text { to happen in the future. }\end{array}$ & 30 & 0.37 \\
\hline $\begin{array}{l}\text { 22] I often have the experience of thinking of someone and soon afterwards } \\
\text { that particular person calls or shows up. }\end{array}$ & 60 & 0.36 \\
\hline 23] I sometimes feel that I have had an out of body experience. & 19 & 0.35 \\
\hline $\begin{array}{l}\text { 24] When I sing or write something, I sometimes have the feeling that } \\
\text { someone or something outside myself directs me. }\end{array}$ & 14 & 0.29 \\
\hline $\begin{array}{l}\text { 25] During my life, I have had intense religious experiences which } \\
\text { influenced me in a very strong manner. }\end{array}$ & 11 & 0.25 \\
\hline
\end{tabular}

\subsection{Reliability}

Test-retest stability ( 6 weeks) of the final CEQ version was found to be fairly good $(r=0.95)$ in a sample of 17 undergraduate students (14 women; mean age: 22.6 years), mean CEQ scores on the two occasions being 7.7 (S.D. =4.7) and 7.1 (S.D.=4.5), respectively. Likewise, internal 
consistency in a separate sample of 99 undergraduate students (79 women; mean age: 21.2 years) was adequate: Cronbach's alpha $=0.72$.

In a third study, factor analysis (principal component with varimax rotation) was performed on CEQ scores of 332 high school students, university students, and university employees (172 women; mean age: 22.7 years; range 16-60 years). Nine factors with an eigenvalue of greater than 1.0 were extracted. Together, these factors explained $56 \%$ of the CEQ variance. However, inspection of the scree-plot suggested a single-factor solution (eigenvalue: 3.8 ) that explained 15\% of the variance. While this is a rather small proportion, it should be noted that of the 25 items, only four had a corrected item-to-total correlation smaller than 0.20 . Table 1 shows the corrected item-to-total correlations as well as percentages of the respondents who endorsed each item. Some authors (e.g. Raine, 1991) have argued that if fewer than $10 \%$ of the respondents endorse an item and/or if the corrected item-to-total correlation for an item is below 0.15 , that particular item should be deleted from the scale. As can be seen in Table 1, endorsement rates exceeded the $10 \%$ level, while correlations were always greater than 0.15 (all $P$ 's $<0.05$ ). Cronbach's alpha for CEQ scores in this sample was, again, satisfactory: 0.76. Fig. 1 shows the frequency distribution of CEQ scores in this sample. Skewness and kurtosis parameters indicated that CEQ scores were normally distributed (skewness $=0.34$; S.E. $=0.13$; kurtosis $=-0.32$; S.E. $=0.27$ ). CEQ scores were not related to age $(r=0.01)$. Neither were there differences in CEQ scores between men and women, means being 9.2 (S.D. $=4.4)$ and 8.7 (S.D. $=4.0)$, respectively $[t(330)<1.0]$.

\subsection{Validity}

In study 2 ( $n=99$; cf. supra), we also asked respondents whether they ever had encountered paranormal phenomena and, if so, whether they could provide us with a brief description of their most intense paranormal experience. Students who reported paranormal experiences $(n=28)$ had higher CEQ scores than those without such experiences $(n=71)$, means being 9.5 (S.D. $=3.3)$ and 7.8 (S.D. $=3.9$ ), respectively $[t(97)=2.0, P<0.05]$. As well, within the subsample of those who were willing to write down a brief description of their most intense paranormal experiences $(n=18)$, CEQ scores tended to be positively related $(r=.37, P=0.07)$ to the eccentricity of the paranormal experiences as rated by an independent judge on a 10-point scale (anchors: $0=$ quite normal; $10=$ extremely bizarre). This finding is reminiscent of Spanos et al.'s (1993) finding of a correlation between fantasy proneness as tapped by the ICMI and the intensity of UFO reports.

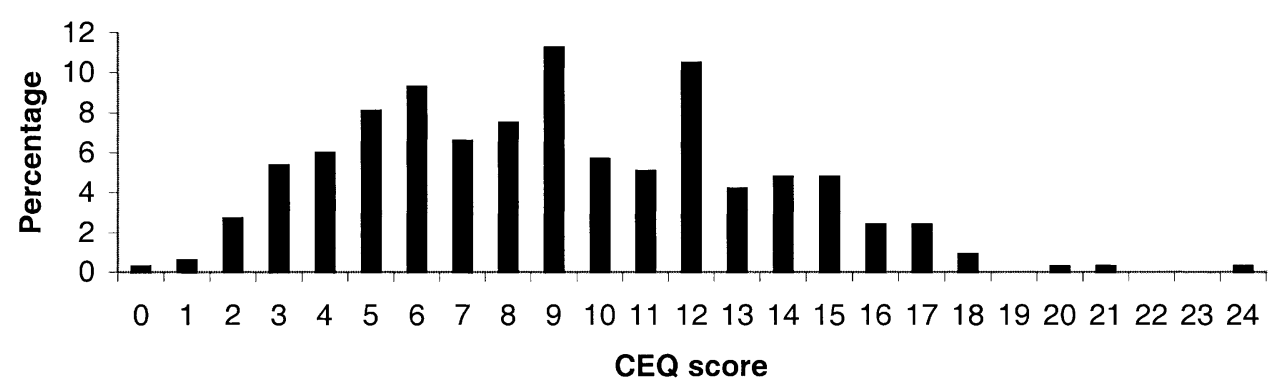

Fig. 1. Distribution (proportions of total sample) of total Creative Experiences Questionnaire (CEQ) score $(n=332)$. 
In a fourth study, we compared four groups of individuals with each other: students $(n=116$; 93 women), amateur actors and actresses ( $n=18 ; 13$ women), regular visitors of exhibitions about paranormal issues ( $n=19 ; 10$ women), and so called "fantasy role players" ( $n=13 ; 8$ women), i.e. people who spend a great deal of their free time to re-enact great historical events (e.g. the Waterloo battle). A one-way analysis of variance yielded a significant result, even when age and sex were entered as covariates: $F(3,161)=7.3, P<0.05$. Follow-up $t$-tests showed that amateur actors and actresses, paranormal visitors, and fantasy role players did not differ from each other in terms of average CEQ scores (all P's > 0.14), means being 10.8 (S.D. = 3.9), 11.1 $($ S.D. $=4.4)$, and 13.2 (S.D. =4.4), respectively. Yet, all these groups differed significantly from the sample of undergraduate students (all $P$ 's $<0.01$ ), whose mean CEQ score was 8.3 (S.D. = 3.9).

\subsection{Correlates}

Given its adequate psychometric properties, we decided to use the CEQ in a number of separate studies. Some of these studies were concerned with memory illusions, while others addressed traits that are relevant from a psychopathological point of view (e.g. dissociation, schizotypy). Below, we briefly summarize results from these studies inasmuch as they may shed some further light on the psychometric qualities of the CEQ.

As a side issue in a study on a memory illusion known as imagination inflation (Garry, Manning, Loftus \& Sherman, 1996), we (Horselenberg, Merckelbach, Muris, Sijsenaar \& Spaan, 2000) examined the connection between fantasy proneness as indexed by the CEQ and the tendency to endorse socially desirable responses. Thus, we had students $(n=79 ; 59$ women $)$ fill out the CEQ together with the 33-item Social Desirability Scale (Crowne \& Marlow, 1964). There was no correlation between CEQ scores and social desirability: $r=0.03$.

In a study on a memory illusion termed the false fame effect (Jacoby, Kelley, Brown \& Jasechko, 1989), we (Merckelbach, Horselenberg, Wessel, Rassin \& Verhoeven, 2000) obtained CEQ scores and scores on the 34-item Tellegen Absorption Scale (TAS; Tellegen \& Atkinson, $1974)$ in a sample of 39 students (27 women). A Pearson product-moment correlation of 0.70 $(P<0.01)$ was found between the two measures, a finding that one expects when it is assumed that fantasy proneness is a "close cousin" of absorption (e.g. Allen \& Coyne, 1995; Kihlstrom et al., 1994). Interestingly, research relying on the ICMI as an index of fantasy proneness reported correlations with TAS of a similar magnitude (e.g. $r=0.77$; Platt, Lacey, Iobst \& Finkelman, 1998).

In a study on the effects of retrieval on metamemory judgments, we (Merckelbach, Wiers, Horselenberg \& Wessel, 2000) recently examined the connection between CEQ scores and scores on the 44-item ICMI version described by Myers (1983). A sample of 52 undergraduate women (mean age: 20.7 years) completed both questionnaires. The Pearson product-moment correlation between the scales turned out to be $0.77(P<0.001)$, a finding that further underlines the validity of the CEQ.

Schizotypy is a trait that has often been related to fantasy proneness (e.g. Allen \& Coyne, 1995). In a recent study (Merckelbach, Rassin \& Muris, 2000), we linked CEQ scores of undergraduate students $(n=152 ; 119$ women) to their scores on the 37-item Claridge schizotypal personality scale (STA; Claridge \& Broks, 1984). STA primarily taps the cognitive and social anxiety 
aspects of schizotypy. A Pearson product-moment correlation of 0.61 was found between STA and fantasy proneness as measured by the CEQ.

In a series of studies (Merckelbach et al., 1999; Merckelbach, Muris, Horselenberg \& Stougie, 2000; Merckelbach, Muris, Rassin \& Horselenberg, 2000), we looked at the correlation between CEQ scores and dissociativity as measured by the 28-item DES (Bernstein \& Putnam, 1986). These studies were based on undergraduate samples that varied from $n=42$ to $n=77$. Pearson product-moment correlations between CEQ and DES scores were always highly significant and ranged from 0.47 to 0.63 . These findings replicate the substantial correlations between ICMI scores and DES that have been reported in the literature (e.g. Bryant, 1995; Rauschenberg \& Lynn, 1995; Silva \& Kirsch, 1992).

\section{Discussion}

The CEQ was designed as a brief and simple research measure of fantasy proneness. The results presented above show that this ambition stands up to empirical testing. First, the CEQ possesses adequate reliability in terms of test-retest stability and internal consistency. Second, the CEQ has predictive validity in the sense that certain categories of individuals who are known to exhibit fantasy prone characteristics (e.g. people with paranormal experiences, amateur actors) display higher scores on this scale than do control individuals. Third, the CEQ demonstrates concurrent validity in that it correlates with another index of fantasy proneness (i.e. ICMI) as well as with measures that tap the closely related concepts of absorption, schizotypy, and dissociativity. Taken together, the current results indicate that the CEQ is a psychometrically sound research instrument.

As to its application, we believe that the CEQ might be a useful tool in several research domains. An obvious example is the study of paranormal experiences and their developmental origins (e.g. Lawrence et al., 1995). Another area is the experimental analysis of pseudomemories. Recent studies have identified a number of manipulations (e.g. imagining fictitious childhood events; writing about fictitious events) that may produce pseudomemories in a subgroup of participants (e.g. Garry et al., 1996; Horselenberg et al., 2000). It would be highly relevant to know how these participants differ from people who are not susceptible to such manipulations. There are some preliminary indications that fantasy proneness might contribute to susceptibility to pseudomemories (e.g. Hyman \& Billings, 1998). Thus, a systematic analysis of the way in which fantasy proneness might interact with certain manipulations to produce robust pseudomemories is warranted and the CEQ might be a useful tool for that purpose.

Studies on screening instruments specifically designed for the detection of malingering may also profit from instruments such as the CEQ. One common research strategy in this field is to compare test performance of patients suspected of malingering with that of simulators, who are often students instructed to feign a certain condition (e.g., schizophrenia; see for examples, Smith, 1997). The outcome of such simulation designs may heavily depend on the role-playing talents of simulators. Fantasy proneness measures may be helpful in recruiting talented simulators who may serve as optimal controls in malingering research.

At a more theoretical level, it remains to be seen how fantasy proneness relates to various super traits specified in hierarchical personality models (Eysenck \& Eysenck, 1985). Some authors have 
suggested that fantasy proneness corresponds to the openness to experience factor in the Big Five taxonomy (e.g. McCrae \& Costa, 1997). On the other hand, openness to experience is a rather broadly defined and, therefore, controversial dimension (e.g. Kihlstrom et al., 1994). In terms of the more parsimonious Eysenckian model, there is no obvious correspondence between fantasy proneness and lower-order and super traits specified by this model. What can be said with some confidence is that there are robust correlations between fantasy proneness, dissociation, schizotypy, and absorption. Yet, the theoretical significance of these correlations is far from clear. It is possible that these overlapping traits are shaped by aversive childhood experiences (e.g. Allen \& Coyne, 1995; Lawrence et al., 1995). However, it may also be the case that they originate from extreme, but essentially normal variations in certain neuronal processes (e.g. limbic hyperactivity; Saver \& Rabin, 1997). Clearly, these issues await further investigation.

\section{References}

Allen, J. G., \& Coyne, L. (1995). Dissociation and the vulnerability to psychotic experience. Journal of Nervous and Mental Disease, 183, 615-622.

Bernstein, E. M., \& Putnam, F. W. (1986). Development, reliability, and validity of a dissociation scale. Journal of Nervous and Mental Disease, 174, 727-735.

Braffman, W., \& Kirsch, I. (1999). Imaginative suggestibility and hypnotizability: an empirical analysis. Journal of Personality and Social Psychology, 77, 578-587.

Bryant, R. A. (1995). Fantasy-proneness and recall of childhood abuse. In G. D. Burrows, \& R. O. Stanley, Contemporary International Hypnosis (pp. 109-117). New York: Wiley.

Claridge, G., \& Broks, P. (1984). Schizotypy and hemisphere function: theoretical considerations and the measurement of schizotypy. Personality and Individual Differences, 5, 633-648.

Crowne, D., \& Marlow, D. (1964). The approval motive. New York: Wiley.

Eysenck, H. J., \& Eysenck, M. W. (1985). Personality and individual differences. New York: Plenum Press.

Garry, M., Manning, C. G., Loftus, E. F., \& Sherman, S. J. (1996). Imagination inflation: imagining a childhood event inflates confidence that it occurred. Psychonomic Bulletin \& Review, 3, 208-214.

Horselenberg, R., Merckelbach, H., Muris, P., Sijsenaar, M., \& Spaan, V. (2000). Imagining fictitious childhood events: the role of individual differences in imagination inflation. Clinical Psychology and Psychotherapy, 7, 128-137.

Hyman, I. E., \& Billings, F. J. (1998). Individual differences and the creation of false memories. Memory, 6, 1-20.

Jacoby, L. J., Kelley, C., Brown, J., \& Jaeschko, J. (1989). Becoming famous overnight: Limits on the ability to avoid unconscious influences of the past. Journal of Personality and Social Psychology, 56, 326-338.

Kihlstrom, J. F., Glisky, M. L., \& Angiulo, M. J. (1994). Dissociative tendencies and dissociative disorders. Journal of Abnormal Psychology, 103, 117-124.

Lawrence, T., Edwards, C., Barraclough, N., Church, S., \& Hetherington, F. (1995). Modelling childhood causes of paranormal belief and experience: childhood trauma and childhood fantasy. Personality and Individual Differences, $19,209-215$.

Lynn, S. J., \& Rhue, J. W. (1988). Fantasy proneness: Hypnosis, developmental antecedents, and psychopathology. American Psychologist, 43, 35-44.

McCrae, R. T., \& Costa, P. T. (1997). Conceptions and correlates of openness to experience. In R. Hogan, J. Johnson, \& S. Briggs, Handbook of personality psychology (pp. 825-847). San Diego: Academic Press.

Merckelbach, H., Muris, P., \& Rassin, E. (1999). Fantasy proneness and cognitive failures as correlates of dissociative experiences. Personality and Individual Differences, 26, 961-967.

Merckelbach, H., Rassin, E., \& Muris, P. (2000). Dissociation, schizotypy, and fantasy proneness in undergraduate students. Journal of Nervous and Mental Disease, 188, 428-431.

Merckelbach, H., Muris, P., Horselenberg, R., \& Stougie, S. (2000). Dissociation, reality monitoring, and response bias. Personality and Individual Differences, 28, 49-58. 
Merckelbach, H., Muris, P., Rassin, E., \& Horselenberg, R. (2000). Dissociative experiences and interrogative suggestibility in college students. Personality and Individual Differences, 29, 1133-1140.

Merckelbach, H., Wiers, R., Horselenberg, R., \& Wessel, I. (2001). Effects of retrieving childhood events on metamemory judgments depend on the questions you ask. British Journal of Clinical Psychology (in press).

Merckelbach, H., Muris, P., Schmidt, H., Rassin, E., \& Horselenberg, R. (1998). De Creatieve Ervaringen Vragenlijst als maat voor "fantasy proneness" [The Creative Experiences Questionnaire (CEQ) as a measure of fantasy proneness]. De Psycholoog, 33, 204-208.

Merckelbach, H., Horselenberg, R., Wessel, I., Rassin, E., \& Verhoeven, C. (2000). Beroemd of toch niet: persoonlijkheidsverschillen en het false fame effect [Famous or not: individual differences and the false fame effect]. Nederlands Tijdschrift voor de Psychologie, 54, 235-240.

Myers, S. A. (1983). The Wilson-Barber Inventory of Childhood Memories and Imaginings: children's form and norms for 1337 children and adolescents. Journal of Mental Imagery, 7, 83-94.

Nicholls, J. G., Licht, B. G., \& Pearl, R. A. (1982). Some dangers of using personality questionnaires to study personality. Psychological Bulletin, 92, 572-580.

Platt, R. D., Lacey, S. C., Iobst, A. D., \& Finkelman, D. (1998). Absorption, dissociation, and fantasy-proneness as predictors of memory distortion in autobiographical and laboratory-generated memories. Applied Cognitive Psychology, 12, 77-89.

Raine, A. (1991). The SPQ: A scale for the assessment of schizotypal personality based on DSM-III-R criteria. Schizophrenia Bulletin, 17, 555-564.

Rauschenberg, S. L., \& Lynn, S. J. (1995). Fantasy proneness, DSM-III-r axis I psychopathology, and dissociation. Journal of Abnormal Psychology, 104, 373-380.

Rhue, J. W., \& Lynn, S. J. (1987). Fantasy proneness: developmental antecedents. Journal of Personality, 55, $121-137$.

Saver, J. L., \& Rabin, J. (1997). The neural substrates of religious experiences. Journal of Neuropsychiatry and Clinical Neurosciences, 9, 498-510.

Silva, C. E., \& Kirsch, I. (1992). Interpretive sets, expectancy, fantasy proneness, and dissociation as predictors of hypnotic response. Journal of Personality and Social Psychology, 63, 847-856.

Smith, G. P. (1997). Assessment of malingering with self-report instruments. In R. Rogers, Clinical assessment of malingering and deception (pp. 351-370). New York: Guilford.

Spanos, N. P., Cross, P. A., Dickson, K., \& DuBreuill, S. C. (1993). Close encounters: an examination of UFO experiences. Journal of Abnormal Psychology, 102, 624-632.

Tellegen, A., \& Atkinson, G. (1974). Openness to absorbing and self-altering experiences ("absorption"), a trait related to hypnotic susceptibility. Journal of Abnormal Psychology, 83, 268-277.

Wilson, S. C., \& Barber, T. X. (1981). Vivid fantasy and hallucinatory abilities in the life histories of excellent hypnotic subjects ("somnabules"): preliminary report with female subjects. In E. Klinger, Imagery: Vol. 2, concepts, results, and applications (pp. 133-149). New York: Plenum Press.

Wilson, S. C., \& Barber, T. X. (1983). Fantasy-prone personality: implications for understanding imagery, hypnosis, and parapsychological phenomena. In A. A. Sheikh, Imagery: current theory, research, and application (pp. 340-387). New York: Wiley. 